\title{
Metazoan Parasites of Clariid Fishes, Lake Victoria: Reflection of the Original Fauna in the Lake?
}

\author{
Chacha J. Mwita \\ Department of Aquatic Sciences and Fisheries, University of Dar Es Salaam, Dar Es Salaam, Tanzania \\ Email: mwitachacha@udsm.ac.tz
}

Received 12 March 2014; revised 12 April 2014; accepted 19 April 2014

Copyright (C) 2014 by author and Scientific Research Publishing Inc. This work is licensed under the Creative Commons Attribution International License (CC BY). http://creativecommons.org/licenses/by/4.0/

(c) (i) Open Access

\begin{abstract}
A total of 32 parasite species were documented from 658 clariid fishes examined. Thirteen species were nematodes, eleven digeneans, three cestodes, two crustaceans, and the Monogenea, Acanthocephala and Hirudinea were each represented by one species. Of the parasites recovered 16 were identified to species level, 12 to genus and 4 parasites were not identified. Most of the parasites recorded in the present study have been reported in fish of Tanzania and elsewhere, however, there were a few first records, and these included Neogoezia sp., Comephoronema sp., Travnema sp., Quimperia sp. and Gendria tilapiae. It is stipulated that these parasites represent the original fauna of the lake prior to introduction of the alien species. The clariid fish species investigated were a good model for studying the parasites of fish in the lake because of having a variety of parasites some of which being specific to certain clariid fishes, for instance Diplostomum and Tylodelphys species infecting only $C$. gariepinus and the camallanids being typical of the clariid fishes.
\end{abstract}

\section{Keywords}

Metazoan Parasites, Clariid Fishes, Lake Victoria, Tanzania

\section{Introduction}

Lake Victoria is famous for its diverse fish fauna - the cichlids and non-cichlids abound [1]. The fish fauna of the lake includes some species introduced between the 1950s and early 1960s namely, the Nile tilapia, Oreochromis niloticus and Nile perch, Lates niloticus [2]. Following the boom in the Nile perch abundance, fishing activities in Lake Victoria became commercialised. Nowadays the Nile perch is exploited for the external mar- 
ket and this has stimulated the establishment of fish processing factories along the shores of the lake. Other indigenous fish species are exploited for local consumption.

Despite the great interest in commercial exploitation of the fish fauna in the lake, their parasites have received very little attention. Until recently, the works of [3]-[5] [6]-[8] were the only studies on the parasites of fish from Lake Victoria. As well, the majority of the studies are of taxonomical nature. Only a few dealt with parasites as a cause of mortality in wild fish [4] [5]. Studies have shown that when new fish species were introduced in the lake, no attempts were made to remove parasites from fish prior to introduction into the lake [3]. As such, since the original parasite fauna of fishes in the lake were not known prior to the introduction of the new fish species, the current status (indigenous or introduced) of the parasite fauna in Lake Victoria is not well known.

The objective of the present study was to document the parasite fauna of the fishes of the Lake Victoria basin. The clariid fishes are suited for this purpose because most species in this family are indigenous to the lake, and as such they are likely to express the original parasite fauna prior to the introduction of new fish species. The ecology of the clariids that allows them to inhabit diverse habitats, move across great distances, and their omnivorous feeding nature predispose them to a diverse parasite fauna, and further vindicating their suitability for the present study.

\section{Materials and Methods}

\subsection{Study Area}

Lake Victoria, the largest tropical lake in the world, is shared between Tanzania, Uganda and Kenya. The lake lies in shallow continental sag between the two arms of the Great Rift Valley, $1170 \mathrm{~m}$ above sea level. The lake has a maximum depth of $84 \mathrm{~m}$, a volume of $2750 \mathrm{~km}^{3}$, and a surface area of $68,800 \mathrm{~km}^{2}$. Primary inflows to the basin include rivers such as the Kagera in the west and the Mara in the east. All outflows are to the north along the Nile through Lake Kyoga. The mean surface temperature is about $25^{\circ} \mathrm{C}$ while the temperature of deeper layers is about 1 to 2 degrees lower [2]. The present study therefore, covered the surroundings of Bukoba town, the Mwanza Gulf, Speke Gulf, parts of Ukerewe Island and the delta of Mara River (Figure 1).

\subsection{Collection and Examination of Fish for Parasites}

Fish were collected from six localities in Lake Victoria (Figure 1); live fish intended for examination of ectoparasites were transported separately each in a plastic bag to the laboratory in TAFIRI Mwanza centre. Fish were examined immediately for parasites; live fish not examined were kept in an aquarium (TAFIRI Mwanza centre) for no longer than 72 hours before examination. Dead fish not examined the same day were frozen. Handling and general preparations of parasites for microscopy followed standard techniques as by [9] [10] and Shigini (1976) as quoted in [11]. The parasites encountered were identified using keys and descriptions from the literature such as [3] [12]-[20].

\section{Results}

\subsection{Clariid Hosts}

Clariid fishes examined consisted of 319 females and 337 males and the distribution was such that C. gariepinus was found from all the localities surveyed, C. liocephalus from three localities namely Mara bay, Mwanza Gulf and Kagera. Clarias werneri and C. alluaudi were obtained from the Mara bay and Mwanza Gulf. In addition, two specimens of Clariallabes petricola were obtained from the Mwanza Gulf, a specimen of Heterobranchus longifilis, from the Malagarasi River and nineteen specimens of Bagrus docmac were obtained from the Mwanza Gulf and Kagera. The majority of parasites recovered occurred in fish of between $120 \mathrm{~mm}$ to $200 \mathrm{~mm}$ standard length.

\subsection{The Parasite Fauna}

Thirty two parasite species were found from 656 fish examined. Table 1 shows the prevalence and mean number of parasites infecting the seven species of fish examined. Among the 32 parasite species, ten were considered core and predictable namely Paracamallanus cyathopharynx, Procamallanus laevionchus, Contracaecum larvae, Neogoezia sp., Diplostomum mashonense, Allocredium mazoensis, Eumasenia bangweulensis, 


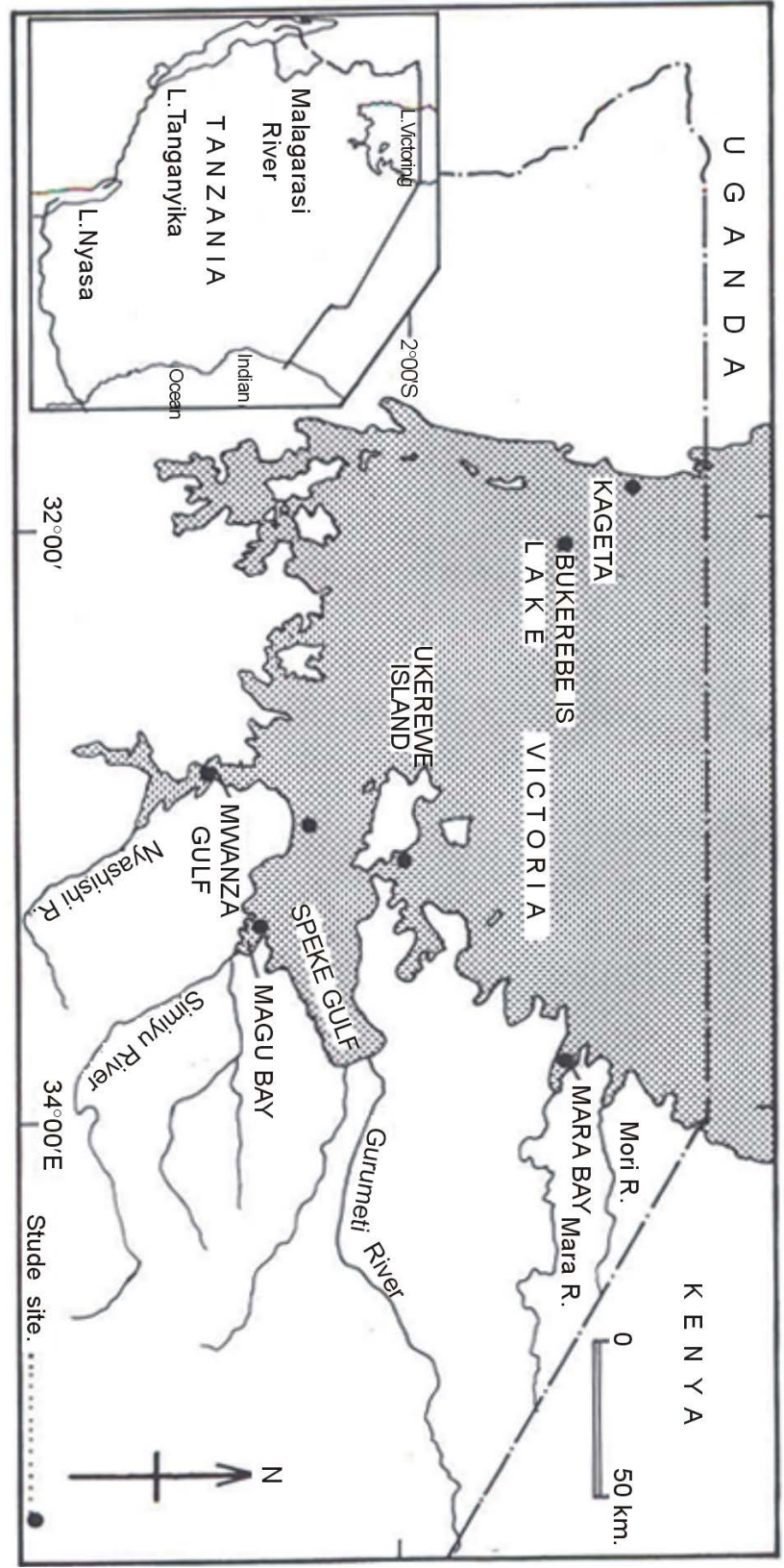

Figure 1. Map of Tanzania showing the sampling points.

Phylodistomum folium, Polyonchobothrium clarias and Monobothrioides woodlandi. The trematodes, Diplostomum mashonense and Tylodelphys species were recovered from the cranial cavity of C. gariepinus only. The crustaceans were recovered from the oral cavity of C. gariepinus, B. docmac and H. longifilis, Gyrodactylus sp. and Clinostomum sp. infected the gills, leeches (Hirudinea: Piscolidae) were recovered from the skin, Eustrongyloides and Contracaecum larvae, and Euclinostomum heterostomum were recovered from the musculature and the rest of the parasites were isolated from the gut.

\section{Discussion}

Most parasites recovered in the present study were also reported by [7] and [21], and have also been reported in fish in Africa [3] [22] [23], and five of the parasites were recorded for the first time in Lake Victoria, Tanzania. Nematodes with 13 representative species were the predominant group of parasites isolated, 11 species were di- 
geneans, 3 cestode species, 2 crustaceans, and the Monogenea, Acanthocephala and Hirudinea were each represented by one species. Of the 32 parasite species recovered, 16 were identified to species level and these included 6 nematodes, 6 trematode, 2 cestode and 2 crustaceans. 12 species were identified to genus level while four were not identified, a nematode from C. alluaudi and C. werneri, a Trematode from C. gariepinus, C. alluaudi and C. werneri, an acanthocephalan from C. alluaudi and a leech from C. gariepinus, C. alluaudi and B. docmac.

Table 1. Prevalence and mean number of parasites (Parenthesis) infecting the seven species of fish examined.

\begin{tabular}{|c|c|c|c|c|c|c|}
\hline & CG $(\mathrm{N}=290)$ & $\mathrm{CA}(\mathrm{N}=81)$ & $\mathrm{CW}(\mathrm{N}=126)$ & CL (N = 139) & $\mathrm{BD}(\mathrm{N}=19)$ & $\mathrm{HL}(\mathrm{N}=1)$ \\
\hline \multicolumn{7}{|l|}{ Nematodes } \\
\hline Paracamallanus cyathopharynx & $42.1(3.1)$ & 7.4(1.3) & $10.3(1.6)$ & 10.1(1.7) & 0 & 0 \\
\hline Procamallanus laevionchus & $1.4(1)$ & 28.4(3.6) & 23(3.7) & $1.4(2.5)$ & 0 & 0 \\
\hline Quimperia sp. & 0 & 0 & 0 & $1.4(6)$ & $5.3(1)$ & $100(8)$ \\
\hline N2 & $1.0(2)$ & 0 & 0 & 0 & 0 & 0 \\
\hline Comephoronema sp. & 0 & 0 & 0 & $1.4(2.5)$ & 0 & 0 \\
\hline Spinitectus petterae & 0 & 0 & $0.8(4)$ & 0 & 0 & 0 \\
\hline Contracaecum larvae & $19(2.6)$ & 8.6(2.9) & $10.3(1.9)$ & $10.1(2.2)$ & 0 & $100(5)$ \\
\hline Eustrongyloides sp. & 3.5(4.8) & 0 & 0 & 0 & 0 & 0 \\
\hline Gendria tilapiae & $2.4(3.4)$ & 0 & 0 & 0 & 0 & 0 \\
\hline Rhabdochona congolensis & $1.4(1.8)$ & 0 & 0 & 0 & 0 & 0 \\
\hline Neogoezia species & 0 & $12.3(3.5)$ & 7.1(11.8) & $9.4(1.8)$ & 0 & 0 \\
\hline Travnema sp. & 0 & 0 & 0 & $0.7(1)$ & 0 & 0 \\
\hline Unidentified sp. & 0 & $3.8(2.5)$ & $6.6(13.1)$ & 0 & 0 & 0 \\
\hline \multicolumn{7}{|l|}{ Trematodes } \\
\hline Diplostomum mashonense & $15.9(92.5)$ & 0 & 0 & 0 & 0 & 0 \\
\hline Tylodelphys spp. 1 \& 2 & $3.1(58.4)$ & 0 & 0 & 0 & 0 & 0 \\
\hline Clinostomum sp. & $2.1(2)$ & $2.5(1)$ & 0 & 0 & 0 & 0 \\
\hline Allocredium mazoensis & $12.1(3.4)$ & $3.7(3)$ & $4.8(4.2)$ & $8.6(34.6)$ & $68.4(29.8)$ & 0 \\
\hline Eumasenia bangweulensis & $2.4(7.1)$ & $6.2(7.4)$ & $4.8(3.3)$ & $15.8(14.7)$ & $52.6(9.2)$ & 0 \\
\hline Astiotrema reniferum & $4.83(4.4)$ & 0 & 0 & $5.8(10.4)$ & 0 & 0 \\
\hline Phylodistomum folium & 0 & 0 & 0 & 0 & $63.2(7.8)$ & 0 \\
\hline Astiotrema sp. & $0.7(1)$ & 0 & 0 & 0 & & 0 \\
\hline Euclinostomum heterostomum & 0 & 0 & 0 & $2.2(3)$ & & 0 \\
\hline $\begin{array}{l}\text { Unidentified sp. } \\
\text { Cestodes }\end{array}$ & \multicolumn{5}{|c|}{ Cestodes } & 0 \\
\hline Polyonchobothrium clarias & $31.4(2.9)$ & 0 & $4(1.4)$ & $1.4(1)$ & 0 & 0 \\
\hline Proteocephalus sp. & $1.4(1)$ & 0 & 0 & 0 & & $100(1)$ \\
\hline $\begin{array}{l}\text { Monobothrioides woodlandi } \\
\text { Crustacean }\end{array}$ & \multicolumn{5}{|c|}{ Crustacean } & 0 \\
\hline Argulus monodi & 0 & 0 & 0 & 0 & 0 & $100(20)$ \\
\hline $\begin{array}{c}\text { Dolops ranarum } \\
\text { Monogenea }\end{array}$ & $1.7(15.2)$ & 0 & 0 & 0 & $5.3(1)$ & 0 \\
\hline $\begin{array}{l}\text { Gyroductylus sp. } \\
\text { Acanthocephala }\end{array}$ & 3.1(1.6) & $1.2(1)$ & $0.8(1)$ & 0 & 0 & 0 \\
\hline $\begin{array}{l}\text { Unidentified sp. } \\
\text { Hirudinea }\end{array}$ & \multicolumn{5}{|c|}{ Hirudinea } & 0 \\
\hline Piscicolid leeches & $0.69(3)$ & $1.9(1.0)$ & 0 & 0 & $5.3(1)$ & 0 \\
\hline TOTAL & 21 & 12 & 12 & 13 & 6 & 4 \\
\hline
\end{tabular}


Paracamallanus cyathopharynx is a common nematode of clariid fishes [7] [22] [24] [25]. This nematode has been reported and re-described by a number of authors [24] [26] [27]. Apart from morphometric measurements, $P$. cyathopharynx is differentiated based on the features of the buccal capsule. The buccal capsule has twochambers, the second being a rentation of the characteristic of the larval buccal capsule [28]. On the dorsum, the anterior chamber has a tooth-like valve that projects longitudinally into the chamber. The posterior prostomium is smooth with chitinous plates on each side. The ventrad side is characterised by a hanging trident that is characteristic of the species. The present material has all these features hence were justifiably identified as Paracamallanus cyathopharynx Baylis, 1923.

Procamallanus laevionchus like Neogoezia species has a smooth buccal capsule the lips of which bear flat expanded chitinous plates. Spinitectus petterae has a retractable funnel-shaped prostomium not supported by chitinous plates. In both $P$. laevionchus and Neogoezia sp. there is a rudimentary basal ring representing the primitive posterior chamber of $P$. cyathopharynx buccal capsule. This feature is not present in the funnel-shaped buccal capsule of $S$. petterae. The integument of $P$. laevionchus is smooth unlike that of Neogoezia sp. in which the transverse striations are raised into rings with no spines in the posterior border. In $S$. petterae however, the posterior border of the rings are provided with spines. P. laevionchus and S. petterae have been recorded from $C$. gariepinus from the Lake Victoria basin [7], and are known to infect several fish species [18] [24]. However, this is the first record of Neogoezia species in Tanzania. The camallanids are typical parasites of the clariids, as they have not been recorded in any other species of fish in Africa.

Rhabdochona congolensis and Comephoronema species recorded in the present study have similar external body morphology. Both have a smooth cuticle and funnel-shaped buccal capsule. These features place the two parasites in the family Rhabdochonidae Skrjabin, 1946 [13]. Unlike Comephoronema species, the buccal capsule in $R$. congolensis has longitudinal thickenings ending in tooth-like projections anteriorly. In Comephoronema species the buccal capsule is simple, smooth and elongate. There is no record of Comephoronema sp. in fish from Tanzania; hence Lake Victoria forms a new geographical distribution for this parasite. $R$. congolensis was identified to species level on the basis of the shape of the buccal capsule. Rhabdochona congolensis differs from $R$. versterae, as the female does not have the finger-like processes on the tip of its tail [5]. Rhabdochona versterae was described by [29] from the intestine of the spot-tailed robber, Alestes imberi Peters 1852 in South Africa. Rhabdochona congolensis was recovered from the intestine of Clarias gariepinus.

The larvae of Contracaecum species were recovered from the tissues of all clariid fishes examined. This nematode is characterised by traverse striations on the anterior region. Contracaecum species are whitish in colour, small to large in size, inhabiting the abdominal cavity and muscle tissues of a number of fish species. Previous records of this parasite in the Lake Victoria basin exist [5]-[7].

It is the first time that a Travnema species is reported from a fish in Lake Victoria. This nematode has simple lips and a flask-shaped oesophagus. The present material was only identified to the genus level. Another nematode that was recorded for the first time in Lake Victoria, thus a new geographical distribution, was Gendria tilapiae identified based on its simple buccal capsule, the tip of which is surrounded by papillae. The oesophagus is single i.e., not divided into parts.

Quimperia species were identified by the presence of lateral alae extending from the base of the lips to the cervical region and a club-shaped muscular oesophagus. These nematodes were recovered from the intestine of C. liocephalus and H. longifilis and Lake Victoria and the Malagarasi River, form new geographical distributions.

Among the 11 species of digeneans recorded in the present study, 6 were identified to species level based on morphological appearance. Eumasenia bangweulensis Beverley-Burton, 1962 for instance, was identified by its funnel-shaped oral sucker surrounded by a double row of alternating spines. The spines on the integument become sparse towards the posterior extremity. This trematode has a prominent cirrus sac containing an armed ejaculatory duct. E. bangweulensis was first described by [15] from Clarias mellandi in Southern Africa, and several species of this genus have been reported to infect freshwater siluroids in many parts of Africa [3].

Astiotrema reniferum unlike Allocredium mazoensis has a subterminal oral sucker, spined integument, with spines becoming sparse towards the posterior extremity. The major features of this trematode are the tandem arrangement of the gonads and sparse distribution of the eggs in utero starting just behind the acetabulum. The vitellaria are located to the lateral sides of the body. A. reniferum has been recorded from the intestine of several species of fish in Africa [3] [7] [15]. A. mazoensis on the other hand has a terminal oral sucker and an unarmed integument. The gonads are located just behind the ventral sucker obscured by an egg-filled uterus extending to 
cover the whole of the posterior body. A. mazoensis infects only freshwater fish and has been reported from all the continents of the world [3].

The family Clinostomidae has four genera namely Euclinostomum identified by its numerous coeccal branches, Clinostomoides and Nephrocephalus with a posteriorly positioned genital system, and the genus Clinostomum with a medially located genital complex and a V-shaped excretory vesicle [5] [12]. In view of the above features two genera were represented in the present study, namely Euclinostomum and Clinostomum. Euclinostomum heterostomum was distinguished based on its similarity to the material presented in [5]. E. heterostomum was recovered from the muscular tissues just behind the eye socket on Clarias liocephalus. It occurred as a yellowish encapsulated worm. Clinostomum species was recovered as a whitish cyst on the gills of Clarias gariepinus. The trematode was identified based on its simple intestinal caeca ending into a V-shaped structure. Clinostomid species are known to infect fish from many families in Africa [5] [7] [30].

The metacercariae of the compound genus Diplostomum fall under two groups, Diplostomum type and Tylodelphys type according to [31]. The metacercaria of Diplostomum mashonense Beverley-Burton, 1963 recovered from the cranial cavity of C. gariepinus in the present study, is identified by its flat, oval body with a border between the fore and hind body. The metacercaria has a round Brandes organ with a vertical slit, oval calcareous bodies and well-developed pseudosuckers. On the other hand Tylodelphys sp $1 \& 2$ recovered in this study are elongate, very active when alive with the border between the fore and hind body not distinct. The longitudinal, oval Brandes organ is placed near the posterior end of the body; oval calcareous bodies, but the pseudosuckers are not evident. The two species however are distinguished by their relative body size; Tylodelphys sp 1 is twice as large as Tylodelphys sp 2. Previous records on metacercariae of the genus Diplostomum in clarias spp. from Africa include [16] [25] [32], and those from Tanzania include [7] [8] [11] [27]. The three diplostomids have never been recorded in any other fish in Africa except C. gariepinus and thus are typical clariid parasites.

Phyllodistomum folium was recovered from the urinary bladder of Bagrus docmac and identified by its foliate hindbody and a tapering forebody. The testes were intercecal, ovaries submedian and the uterus occupies almost the whole of the posterior body just behind the ventral sucker. Phyllodistomum species has been reported in $C$. gariepinus in southern Africa [23], and from various siluroids and Mastercembelus species elsewhere in Africa [5].

Astiotrema sp. was recovered from the intestine of $B$. docmac. The trematode has an elongate body and a cup-shaped oral sucker with circumoral spine. The gonads are positioned at the posterior end. The uterus fills all of the body between the ventral sucker and the anterior testis. The oral sucker differs from the funnel-shaped oral sucker of Eumasenia bangweulensis.

Among the three cestodes recorded in the present study, two were identified based on their similarities to cestodes previously recovered from C. gariepinus in Lake Victoria by [7]. These include Polyonchobothrium clarias characterised by a scolex bearing two rows of hooklets. $P$. clarias inhabits part of the duodenum, bile duct and the gall bladder and is widely distributed in African freshwater fishes [5] [33]. The other, Monobothrioides woodlandi was identified due to its longitudinal furrows or grooves on the scolex. M. woodlandi was first described from the intestine of Clarias mellandi in Zambia [34]. The present material resembles those reported by the above authors and by [7], and hence assigned to the same group. Of the three cestodes, Proteocephalus species could not be identified to species level. This cestode has four rounded suckers; immature proglotids were wider than longer while the mature ones were longer than wider. Proteocephalus species recovered in the present study resembles the material reported by [7] and efforts are underway to identify it to species level.

The final group of parasites encountered in the present study were ectoparasites such as crustaceans, Hirudinea, monogeneans and an unidentified intestinal acanthocephalan. The crustaceans recovered were identified as Dolops ranarum similar to the material reported by [7], hence assigned to the same group. The second was identified as Argulus monodi due to its similarity to the material reported by [5]. Argulus monodi was recovered from the posterior part of the oral cavity of Heterobranchus longifilis from the Malagarasi River.

The Hirudinea, Piscolid leeches and the Monogenea, Gyrodactylus species infect the skin and gills of many siluroid fishes. Materials recorded in the present study are similar to those described from C. gariepinus in Lake Victoria [7]. These parasites have also been reported from a wide range of fishes [5] [30] [35].

In summary, 32 parasites species were documented from the nematodes, cestodes, trematodes, crustaceans, monogeneans, acanthocephalans and hirudeneans. With such a wide representation, the study concludes that 
these parasites were possibly the original fauna in Lake Victoria prior to its drying and subsequent introduction of the alien species.

\section{Acknowledgements}

Thanks are extended to Lake Victoria Management Project (LVEMP I) and Lake Victoria research initiative (VicRes) for financial support and TAFIRI Mwanza centre for technical staffs and laboratory space and the University of Dar Es Salaam for availing time to conduct this study.

\section{References}

[1] Eccles, D.H. (1992) FAO Species Identification Sheets for Fishery Purposes. Field Guide to the Freshwater Fishes of Tanzania. UNDP Project URT/87/016, Rome, 145 p.

[2] Witte, F. and Van Densen, W.L.T. (1995) Fish Stock and Fisheries of Lake Victoria. A Handbook for Field Observation, Samara Publishing House, Samara House, Cardigan, Dyfed, 404 p.

[3] Khalil, L.F. and Thurston, J.P. (1973) Studies on the Helminth Parasites of Freshwater Fishes of Uganda Including the Descriptions of Two New Species of Digeneans. Revue de Zoologice et Botanice Africaines, 87, 210-247.

[4] Paperna, I. (1979) Monogenea of Inland Fresh Water Fish in Africa. Annals of Zoology, 22, 131 p.

[5] Paperna, I. (1980) Parasites, Infections and Diseases of Fish in Africa. CIFA Technical Paper, 7, 216 p.

[6] Mbahinzireki, G.B.A. (1984) Parasito-Fauna of Haplochromine Species (Pisces: Cichlidae) from Mwanza Gulf of Lake Victoria. M.Sc. Thesis, University of Dar-Es-Salaam, 157 p.

[7] Mwita, C. and Nkwengulila, G. (2004) Parasites of Clarias gariepinus (Burchell, 1822) (Pisces: Clariidae) from the Mwanza Gulf, Lake Victoria. Tanzania Journal of Science, 30, 53-62.

[8] Musiba, M.J. (2004) Some Aspects of the Life History of Diplostomum Species (Digenea: Diplostomatidae) Infecting Clarias Species (Clariidae) of Lake Victoria. MSc Thesis, University of Dar-Es-Salaam, 100 p.

[9] Moravec, F., Nasincova, V. and Scholz, T. (1991) Training Course on Fish Parasites: Methods of Investigation of Endoparasitic Helminths. Institute of Parasitology, Czechoslovak Academy of Science.

[10] Moravec, F., Nasincova, V. and Scholz, T. (1991) Training Course on fish parasites: Demonstration and Determination of Monogenea. Institute of Parasitology, Czechoslovak Academy of Sciences, $52 \mathrm{p}$.

[11] Nkwengulila, G. (1995) Epidemiology and Taxonomy of Diplostomum Species (Trematoda: Diplostomatidae) Infecting Fish of Llyn Tegid, North Wales and Ruvu Basin-Tanzania. Ph.D. Thesis, University of Liverpool, 321 p.

[12] Yamaguti, S. (1958) Systema Helminthum. I. The Digenetic Trematodes of Vertebrates. Intersience Publishers, New York \& London, 979 p.

[13] Yamaguti, S. (1959) Systema Helminthum. II. The Cestodes of Vertebrates. Interscience Publishers, New York \& London, $860 \mathrm{p}$.

[14] Yamaguti, S. (1961) Systema Helminthum. Vol. III. The Nematodes of Vertebrates, Pt. II \& I. Interscience Publishers, New York \& London, 1261 p.

[15] Beverley-Burton, M. (1962) Some Trematodes from Clarias sp. in the Rhodesians, Including Allocredium mazoensis $\mathrm{n}$. sp. and Eumasenia bangweulensis n. sp. and Comments on the Species of the Genus Orientocredium Tubangui, 1931. Proceedings of the Helminthological Society of Washington, 29, 103-115.

[16] Beverley-Burton, M. (1963) A New Strigeid Diplostomum (T) mashonense n. sp. (Trematoda: Diplostomatidae) from the Grey Heron, Ardea cinerea L., in Southern Rhodesia with an Experimental Demonstration of Part of the Life Cycle. Revue de Zoologice de Botanique Africaines, 68, 291-306.

[17] Niewiadomska, K. (1963) Further Studies on the Biology and Taxonomy of Trematodes of the Genus Tylodelphys Diesing, 1850 (Diplostomatidae). Acta Parasitologica Polonica, 31, 283-305.

[18] Dawes, B. (1968) The Trematoda: With Special Reference to British and Other European Forms. Cambridge University Press, London, 644 p.

[19] Boomker, J. (1993) Parasites of South African Freshwater Fish. V. Description of Two New Species of the Genus Spinitectus Fourment, 1883 (Nematoda: Cystidicolidae). Onderstepoort Journal of Veterinary Research, 60, 139-145.

[20] Khalil, L.F. and Polling, L. (1997) Checklist of the Helminth Parasites of African Freshwater Fishes. University of the North, Pietersburg, 185 p.

[21] Nkwengulila, G. and Mwita, C. (2004) Spatial Distribution of Parasites along the Gut of the Catfish Clarias gariepinus (Burchell, 1822) (Clariidae) from the Mwanza Gulf, Lake Victoria. Tanzania Journal of Science, 30, 63-70.

[22] Khalil, L.F. (1971) Checklist of the Helminth Parasites of African Freshwater Fishes. Technical Communication of the 
Commonwealth Institute of Helminthology, CAB, Commonwealth Agricultural Bureaux, Slough, 80 p.

[23] Van As, J.G. and Basson, L. (1984) Checklist of Freshwater Fish Parasites from Southern Africa. South African Journal of Wildlife Research, 14, 49-61.

[24] Moravec, F. (1974) The Development of Paracamallanus cyathopharynx (Baylis, 1923) (Nematoda: Camallanidae). Folia Parasitologica (Praha), 21, 333-343.

[25] Mashengo, S.N. and Saayman, J.E. (1981) Observations on the Prevalence of Nematode Parasites of the Catfish, Clarias gariepinus (Burchell 1822), in Lebowa, South Africa. South African Journal of Wildlife Research, 11, 46-48.

[26] Boomker, J. (1982) Parasites of South African Freshwater Fish. I. Some Nematodes of the Catfish [Clarias gariepinus (Burchell, 1822)] from the Hartbeespoort Dam. Onderstepoort Journal of Veterinary Research, 49, 41-51.

[27] Nkwengulila, G. (1998) Taxonomy and Biology of the Helminth Fauna of the Catfish, C. gariepinus, (Burchell, 1822) (Clariidae) and Tilapia (Cichlidae). Unpublished Report.

[28] Jackson, J.A. and Tinsley, R.C. (1995) Representatives of Batrachocamallanus n.g. (Nematoda: Procamallaninae) from Xenopus spp. (Anura: Pipidae): Geographical Distribution, Host Range and Evolutionary Relationships. Systematic Parasitology, 31, 159-188. http://dx.doi.org/10.1007/BF00009115

[29] Boomker, J. and Petter, A.J. (1993) Parasites of South African Freshwater Fish. III. Rhabdochona (Rhabdochona) versterae n. sp. (Nematoda: Rhabdochonidae) from the Spot-Tailed Robber, Alestes imberi Peters 1852. Onderstepoort Journal of Veterinary Research, 60, 23-27.

[30] Magadza, C.H.D. (1991) Parasites of Fishes of Lake Kariba and Other Fish Studies. ULKRS Bulletin 1/91 University of Zimbabwe Lake Kariba Research Station, Harare, 46 p.

[31] Niewiadomska, K. (1970) An Analysis of Criteria for Generic Differentiation within the Order Strigeidida (La Rue, 1926). Acta Parasitologica Polonica, 18, 277-289.

[32] Khalil, L.F. (1963) On Diplostomulum tregenna, the Diplostomulum Stage of Diplostomum tregenna Nazmi Gohar, 1932 with an Experimental Demonstration of Part of the Life Cycle. Journal of Helminthology, 37, 199-206. http://dx.doi.org/10.1017/S0022149X00003783

[33] Mashego, S.N. and Saayman, J.E. (1989) Digenetic Trematodes and Cestodes of C. gariepinus in Lebowa South Africa. South African Journal of Wildlife Research, 11, 17-20.

[34] Mackiewicz, J.S. and Beverley-Burton, M. (1967) Monobothrioides woodlandi (Cestoidea: Caryophyllidea) from Clarias mellandi, Boulinger (Cypriniformes: Clariidae) in Zambia, Africa. Proceedings of the Helminthological Society of Washington, 34, 125-128.

[35] Ogutu-Ohwayo, R. (1989) The Occurrence of Branchiuran Parasites on the Nile Perch, Lates niloticus (L.), Introduced into Lake Kyoga (Uganda). Revue Zoologica Africa, 103, 183-189. 